\title{
PERJALANAN PENERAPAN SISTEM INFORMASI OPEN SOURCE KOHA DI PERPUSTAKAAN UNIVERSITAS MUHAMMADIYAH SURAKARTA DARI TAHUN 2006 s.d. 2010
}

\author{
Oleh: Maria Husnun*
}

\begin{abstract}
The title of the research is "The chronology of the application of open source information system Koha in the library of Muhammadiyah University of Surakarta from 2006 to 2010." The background of this research is that the development of the information technology demands the library to use the technology. UMS' library was the first private-university library using Koha system as the automatic system in Indonesia.Koha's complete features and its development raised confusion among UMS' library staff. The use of English language and the small number of the community of Koha users in Indonesia sometimes lead to misinterpretation.

The method used in this research was the qualitative method, and its approach was the case study. The reason of using these was that the case happened was unique and the forms of the questions were how and why.

The result of the research was that there were 3 periods of the chronology of Koha application in UMS library, namely: pre-Koha, whilst using Koha, and developing of Koha system.The application of Koha system in UMS library had been in accordance with the cycle of the development of the information system. This cycle includes planning, analyzing, system designing, implementing, operating, evaluating, and developing. The influential factors were: (1) the rectorat's supports, (2) human resource and leadership, (3) trend in the library, (4) integration, (5) the need of the system, (6) the data analyze, (7) communication, (8) good cooperation, (9) socialization, (10) open source, (11) financial condition, (12) the quality of the system, (13) the readiness of the facilities. Besides, the research found that there were some new factors as the theoretical contributions namely: good communication and cooperation, socialization, and the readiness of the facilities. It also found that there was one lost factor, namely: user interface.
\end{abstract}

Key words: Information system, KOHA system.

* Mahasiswa MIPUGM

\section{A. Pendahuluan}

Perkembangan teknologi informasi dan komunikasi yang begitu cepat menuntut perpustakaan sebagai lembaga informasi menggunakan teknologi informasi sebagai alat untuk menjalankan kegiatan sehari-hari. Pemanfaatan teknologi informasi sudah menjadi kebutuhan mutlak bagi perpustakaan untuk mencapai efisiensi dan efektifitas pengelolaan perpustakaan. Melalui teknologi komputer dan informasi yang semakin maju memungkinkan kemudahan-kemudahan dalam pengelolaan perpustakaan. Sistem otomasi dan digitalisasi perpustakaan akan memberi peluang akses yang lebih besar kepada pengguna dan meringankan kerja staf perpustakaan.

Perpustakaan Universitas Muhammadiyah Surakarta (UMS) sejak tahun 1994 sudah menerapkan otomasi dengan sistem pustaka, yang kala itu hanya terbatas pada bagian pengolahan dan penelusuran buku. Tahap selanjutnya pada tahun 2004 berganti sistem informasi Mypus yang berhasil mengotomasikan bagian pengolahan dan penelusuran buku serta bagian sirkulasi dan administrasi anggota. Namun semakin banyak data dan masih sederhana mypus, menuntut perpustakaan UMS untuk kembali mengganti sistem informasi perpustakaannya. Setelah melalui tahap pemilihan, analisis, penilaian dan pertimbangan akhirnya pada Februari 2008 perpustakaan UMS secara resmi memilih dan memanfaatkan sistem informasi perpustakaan open source Koha dalam pengelolaan perpustakaannya.

Koha memiliki fitur yang lengkap dibandingkan dengan sistem open source lainnya dan dapat digunakan untuk semua ukuran perpustakaan. Fiturfitur tersebut dapat digunakan sebagai sistem dalam sirkulasi, katalogisasi, akuisisi, serial, cadangan, manajemen pengelolaan, maupun pengelolaan cabang perpustakaan, dengan daya tampung data yang besar. Koha menggunakan desain database dual yang memanfaatkan kekuatan dari dua jenis database standar industri besar (berbasis teks dan RDBMS). Fitur desain memastikan bahwa Koha dapat dipakai 
untuk memenuhi beban transaksi perpustakaan, apapun ukurannya.

Koha juga dinilai dan diprediksi dapat menąngani setiap kebutuhan sistem informasi perpustakaan. ke depan karena Koha terus dikembangkan oleh teknisi dari berbagai latar belakang dan oleh berbagai perpustakaan untuk dapat memenuhi kebutuhan pengguna. Koha dapat diterapkan pada berbagai ukuran perpustakaan dengan berbagai macam fasilitas. Koha disusun untuk memenuhi standar manajemen perpustakaan sehingga dapat diintegrasikan dengan sistem manajemen lain. Koha berbasis open source, maka teknologinya murah dan terjangkau, bahkan perpustakaan kecil dapat memanfaatkan.

Seperti dalam penerapan Koha di Perpustakaan UMS tidak semua berjalan mulus. Banyak kendala dan masalah yang dihadapi, baik dari segi kesiapan staf, budaya organisasi, infrastruktur dan dukungan manajemen. Lengkapnya fitur Koha tidak serta merta memudahkan staf untuk mengerjakan tugas seharihari, bahkan dinilai lebih rumit dan membuat kebingungan staf perpustakaan dalam pemanfaatan Koha karena berbagai macam data harus dientri melalui sistem. Pencetakan label, barcode dan laporan yang harus melalui beberapa tahap juga terkadang merepotkan dan membuat proses pengolahan menjadi lebih lama. Selain itu modifikasi tampilan yang banyak membuat proses pekerjaan menjadi lebih lambat sehingga kurang efisien dan efektif.

Di samping itu Koha terus dikembangkan oleh penggunanya dari berbagai perpustakaan di dunia sehingga dalam prakteknya sering terjadi pergantian aturan dalam penggunaan Koha. Sehingga tiap ada pergantian dan perkembangan baru tersebut sistem diup-grade yang terkadang menimbulkan masalah dan kebingungan baik staf maupun pengguna perpustakaan. Selain itu pengembangan Koha yang berbahasa Inggris, dan masih sedikit pemakai Koha di Indonesia sering menimbulkan salah penafsiran dalam mengimplementasikan pengembangan sistem yang pada akhirnya proses implementasi pengembangan sistem ini membutuhkan proses dan waktu yang lama. Kurangnya pemahaman para staf dan pengguna perpustakaan terhadap Koha menambah permasalahan yang timbul dari pemanfaatan Koha di perpustakaan UMS. Masalah-masalah yang timbul tersebut antara lain penelusuran koleksi yang harus dilakukan berulang-ulang, pembuatan laporan yang kurang lengkap, pengentrian katalog dua kali (double) yang menyebabkan penumpukan data yang tidak terpakai.

Perpustakaan UMS merupakan perpustakaan perguruan tinggi pertama yang menerapkan Koha di Indonesia. Meneliti tentang perjalanan penerapan Koha di perpustakaan UMS ini merupakan suatu hal yang menarik dan unik untuk dilakukan, karena di perpustakaan ini lah Koha mulai dikembangkan dan diperkenalkan di Indonesia. Padahal di negara-negara lain di dunia sudah banyak perpustakaan-perpustakaan y a $\mathrm{g}$ mengimplementasikan dan mengembangkannya. Bahkan Koha dinilai mampu bersaing dengan sistem informasi perpustakaan lainnya yang berbayar.

Beberapa hal inilah yang mendorong peneliti tertarik untuk meneliti tentang "Perjalananan Penerapan Sistem Informasi Perpustakaan Open Source Koha di Perpustakaan Universitas Muhammadiyah Surakarta dari tahun 2006 s.d. 2010".

\section{B. Rumusan Masalah}

Berdasarkan latar belakang di atas maka masalah yang dapat dirumuskan adalah sebagai berikut:

1. Bagaimana perjalanan penerapan Koha di perpustakaan UMS dari masa ke masa?

2. Faktor-faktor apa saja yang berpengaruh dalam penerapan Koha di perpustakaan UMS?

3. Pelajaran apa yang dapat ditarik dari pengalaman perjalanan penerapan Koha di perpustakaan UMS?

\section{Proposisi "How"}

Penelitian ini menggunakan teori tentang penerapan sistem informasi di organisasi yang diutarakan oleh Nugroho (2008). Menurut Nugroho (2008) penerapan tersebut melalui tahap-tahap sebagai berikut seperti

1. Fase Perencanaan, yaitu dimulai dengan mendefinisikan masalah. Analisis ini dilakukan dengan melihat dari berbagai aspek, misalnya aspek ekonomis, teknis, hukum, waktu dan lain sebagainya.

2. Fase Analisis, yaitu meneliti kebutuhan pemakai informasi dan menentukan tingkat penampilan sistem yang diperlukan untuk memenuhi kebutuhan tersebut.

3. Fase Desain adalah fase perancangan sistem secara lengkap baik dari aspek perangkat keras maupun perangkat lunak. Dalam pengembangan sistem informasi ada dua hal yang harus dirancang yakni aspek perancangan proses dan aspek perancangan data. 
4. Fase Implementasi adalah fase di mana program ditulis, diuji dan disesuaikan sampai memenuhi kebutuhan pemakai. Pada fase ini semua perangkat lunak dan perangkat keras dipasang, dicoba, dan diatur sampai memenuhi harapan yang ditetapkan. Pada tahap ini fase kritis terletak pada fase perpindahan dari sistem lama ke sistem baru.

5. Fase Operasi (Penggunaan) adalah fase di mana sistem informasi mulai digunakan untuk membantu organisasi. Pada fase ini umumnya masih terjadi penyempurnaan-penyempurnaan kecil pada sistem, maupun juga penambahanpenambahan kecil pada kinerja sistem. Pada tahap ini secara teratur dilakukan audit sistem untuk menjamin quality assurance dari kinerja sistem.

6. Fase Evaluasi (Penyempurnaan), yakni fase peningkatan sistem. Dan apabila terjadi penyempurnaan yang bersifat besar maka tahapan pengembangan sistem dapat dimulai kembali dari awal.

Lebih jelasnya dapat dilihat pada gambar berikut ini:

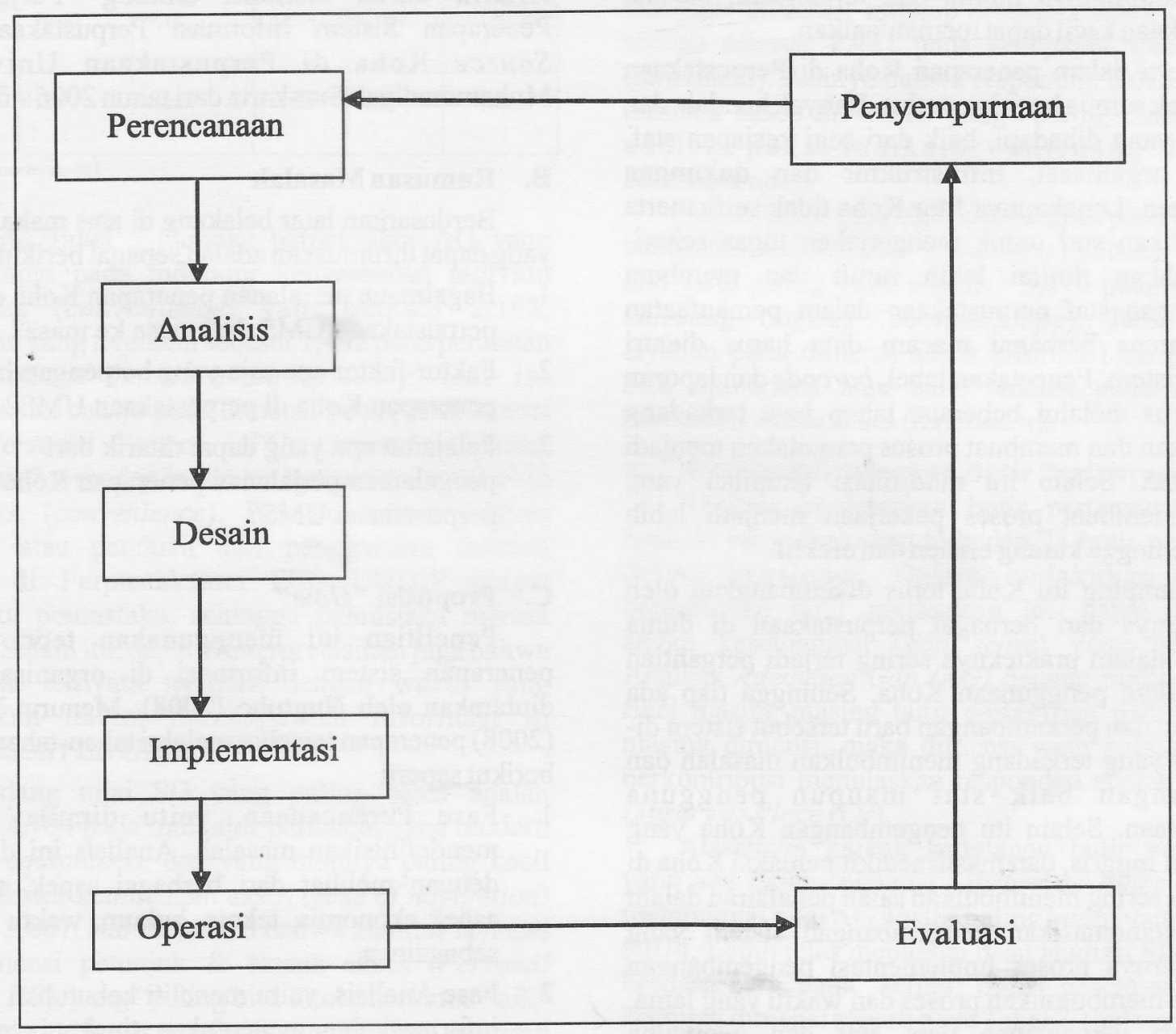

\section{Gambar 1}

Siklus Pengembangan Sistem Informasi

Sumber: Nugroho, Eko. 2008. Sistem Informasi Manajemen, dengan modifikasi 


\section{Proposisi "Why"}

Sementara untuk menjawab pertayaan "Why" penelitian ini menggunakan teori yang disebutkan oleh Burch dan Grunidski (1994) dalam Nugroho (2008) yang menyebutkan bahwa pada umumnya faktorfaktor yang dapat mempengaruhi penerapan sistem informasi di organisasi adalah integrasi, format tatap muka layar tampilan, kekuatan kompetitor, kualitas informasi yang dikehendaki, kebutuhan sistem, pengolahan data, faktor organisasi, kebutuhan untung rugi organisasi, faktor manusia dan masalah hukum. Dari faktor-faktor tersebut yang paling menentukan keberhasilan penerapan suatu sistem informasi adalah faktor manusia, karena manusialah yang menjalankan sistem tersebut. Dengan adanya perubahan pada sistem informasi yang dipakai, maka secara otomatis akan mengubah cara manusia bekerja, belajar dan mengelola suatu organisasi. Untuk itu perlu adanya suatu kesiapan dari SDM organisasi tersebut untuk mau mengubah cara bekerjanya. Kesiapan untuk berubah ini dipengaruhi oleh keyakinan dari dalam diri staf, budaya dan lingkungan kerja.

\section{Metode Penelitian}

Penelitian ini dilakukan dengan mengambil kasus yang terjadi di perpustakaan Universitas Muhammadiyah Surakarta selama proses penerapan sistem open source Koha dari tahun 2006 s.d. 2010. Dipilihnya Perpustakaan UMS, karena Perpustakaan ini merupakan Perpustakaan Perguruan Tinggi Pertama di Indonesia yang menerapkan Sistem Informasi Open Source Koha. Selain itu Perpustakaan UMS juga menjadi rujukan perpustakaanperpustakaan lain di Indonesia yang sudah dan akan menerapkan Koha.

Metode yang akan dipakai dalam penelitian ini adalah metode kualitatif dengan pendekatan studi kasus. Penelitian ini menggunakan metode penelitian studi kasus deskriptif dengan kasus tunggal yang ingin mendeskripsikan fenomena yang terjadi dalam penerapan sistem informasi Koha di perpustakaan UMS. Fenomena ini menjadi unik dan menarik untuk diteliti karena Koha merupakan software perpustakaan open source pertama di dunia dan perpustakaan UMS merupakan perpustakaan perguruan tinggi pertama di Indonesia yang menerapkannya untuk program otomasi. Dengan metode studi kasus ini, peneliti ingin memberikan gambaran secara mendalam tentang penerapan sistem informasi perpustakaan Koha di perpustakaan UMS dari tahun 2006 s.d. 2010.

Teknik Pengumpulan Data menggunakan multisumber bukti (Yin, 2009) yaitu: Dokumentasi, Rekaman Arsip, Wawancara dan Observasi Langsung. Teknik Pemilihan Informan dilakukan dengan cara purposive sampling. Analisis Data yang akan dilakukan pada penelitian ini akan memakai strategi yang mendasarkan pada proposisi teoritis (Yin, 2009) Kemudian proposisi-proposisi yang telah dibuat akan dijadikan landasan untuk membuat serangkaian pertanyaan penelitian, pengumpulan data, reduksi data, display data dan menarik kesimpulan.

Langkah-langkah penelitian yang dilakukan adalah:

1. Merumuskan periodisasi

2. Membahas cara penerapan Koha pada tiap periode (terutama pada periode tertentu)

3. Mengidentifikasi faktor-faktor yang berpengaruh dalam penerapan Koha

4. Membandingkan antara temuan dengan proposisi serta melakukan pembahasan

\section{Pembahasan}

Dalam penelitian ini dipakai 3 periodisasi yang disusun atas dasar kenyataan yang terjadi tentang pengembangan sistem otomasi di Perpustakaan UMS. 3 periode tersebut adalah periode pra Koha, periode Koha, dan periode perluasan pengembangan Koha. Periode pra Koha membahas tentang pertama kali penggunaan sistem otomasi di perpustakaan UMS sampai dengan rencana pergantian ke sistem otomasi Koha. Periode Koha membahas tentang penerapan dan pemanfaatan sistem otomasi Koha di perpustakaan UMS. Sedangkan periode perluasan pengembangan Koha menceritakan tentang usaha perpustakaan UMS untuk memperluas pemanfaatan dan pengembangan Koha di masyarakat.

Apabila digambarkan maka periodisasi tersebut akan tampak pada gambar 2 .

\section{Gambar 2}

\begin{tabular}{|c|c|c|} 
Prakoha & Koha & Perluasankoha \\
\hline 19945.02000 & 2000 s.d 2010 & 2010 s.d sekarang
\end{tabular}


Periode Pra Koha membahas tentang pertama kali penggunaan sistem otomasi di perpustakaan UMS sampai dengan rencana pergantian ke sistem otomasi Koha. Otomasi di perpustakaan UMS sudah dimulai sejak tahun 1994, Software yang dipakai berbasis DOS dan bernama Pustaka. Fitur-fitur yang ada dalam Pustaka di antaranya: Katalogisasi, Sirkulasi, Pencetakan katalog dan barcode serta OPAC. Tahun 2003 , kemudian beralih pada sistem berbasis windows yang diberi nama Mypus. Mypus mampu mengatasi pekerjaan perpustakaan untuk katalogisasi, patron management, sirkulasi (peminjaman-pengembalian, dan report/laporan) Pertengahan 2004, Perpustakaan UMS berniat migrasi ke sistem berbasis web.

Namun programmer yang disewa gagal menyelesaikan sistem yang diinginkan oleh Perpustakaan.

Periode Koha membahas tentang penerapan dan pemanfaatan sistem otomasi Koha di perpustakaan UMS. Tahun 2006, dilakukan perencanaan program otomasi di perpustakaan dengan menganalisis setiap permasalahan-permasalahan yang terjadi dan menganalisis kebutuhan-kebutuhan otomasi seperti apa yang cocok untuk perpustakaan UMS Dari hasil searching dan analisis literatur maka didapat sistem otomasi yang paling pas dan bagus serta sesuai dengan kebutuhan perpustakaan UMS adalah Koha.

Koha kemudian diujicoba dan dipelajari secara intensif serta dimodifikasi untuk kemudian diimplementasikan. Hingga akhir tahun 2007 Koha sudah hampir siap untuk diimplementasikan. Awal 2008, Koha mulai dioperasikan di Perpustakaan UMS bersamaan dengan program stock opname. Kemudian mulai dijalankan pada bagian pengolahan buku, sirkulasi, administrasi anggota dan OPAC. Akhir 2008, Koha mulai dijalankan pada bagian Pengadaan. Pada tahun 2009 Koha berhasil dijalankan pada pengolahan koleksi periodikal, pembuatan laporanlaporan, pencetakan barcode dan label buku serta mensentralisasi proses pembayaran. Awal 2010, Koha mulai diterapkan untuk pengolahan koleksi audio visual (CD \& DVD)

Periode perluasan pengembangan Koha menceritakan tentang usaha perpustakaan UMS untuk memperluas pemanfaatan dan pengembangan Koha di masyarakat. Usaha-usaha tersebut antara lain: menawarkan kerjasama dengan sekolah menengah, menyelenggarakan seminar tentang Koha, melakukan pendampingan dengan Perpustakaan yang memakai Koha, sharing pengalaman.

\section{D.1. Cara Penerapan Koha}

Berdasarkan pada pemaparan tentang periodisasi perkembangan sistem informasi di Perpustakaan UMS, maka didapat suatu grafik perkembangan seperti pada gambar 3 .

\section{Gambar 3. Grafik Perjalanan Perkembangan Penerapan Koha di Perpustakaan UMS}

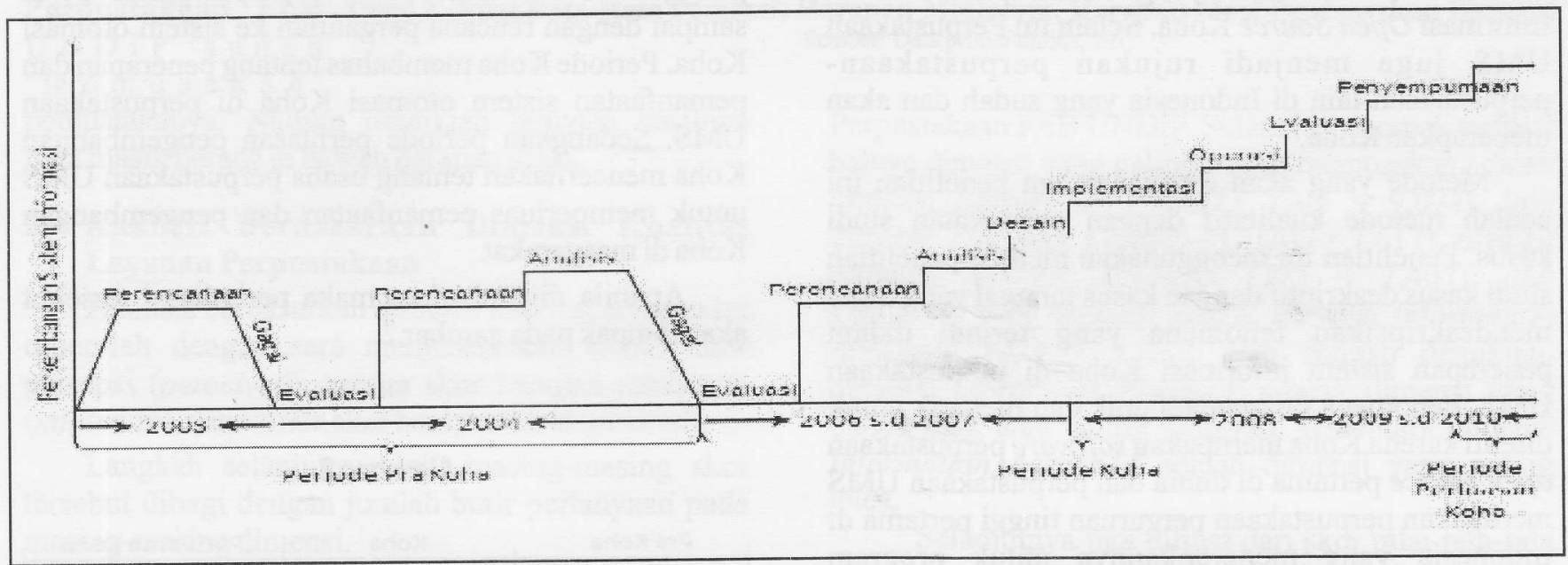


Pada Periode Pra Koha pernah dilakukan beberapa kali perencanaan untuk mengganti sistem informasi ke arah yang lebih baik, berbasis web maupun standar perpustakaan dan sesuai dengan kebutuhan. Namun perencanaan-perencanaan tersebut pada akhirnya gagal diwujudkan. Pada tahun 2003 kegagalan dikarenakan tidak adanya komunikasi dan kerjasama yang baik antar tim otomasi perpustakaan sendiri, juga antara IT perpustakaan yang akan menggunakan dengan IT universitas yang akan merancangkan. Sementara pada tahun 2004, kegagalan disebabkan oleh ketidakmampuan programmer yang disewa Perpustakaan untuk membuat sistem informasi sesuai dengan kebutuhan Perpustakaan.

Baru pada tahun 2006 dimulai kembali perencanaan pergantian sistem otomasi di Perpustakaan UMS. Hal ini dilakukan setelah terpilihnya Kepala baru yang mempunyai keahlian di bidang komputer. Beberapa alasan mengapa perpustakaan UMS harus mengganti sistem otomasinya terungkap dari beberapa wawancara yang dilakukan peneliti dengan para informan, alasanalasan tersebut adalah: (a) Belum mampu menggunakan sistem otomasi yang terintegrasi. (b) Banyak keluhan dari staf tentang sistem otomasi perpustakaan yang ada pada saat itu. (c) Selalu gagal bekerjasama dengan pihak luar dalam pembangunan sistem otomasi perpustakaan. (d) Sistem otomasi yang ada tidak mengadopsi standar umum sistem otomasi perpustakaan. (e) Pada waktu itu perpustakaan belum mengikuti trend teknologi informasi yang menggunakan aplikasi berbasis web dan internet.

Selain alasan-alasan tersebut terungkap pula bahwa sistem otomasi yang dipakai sebelum Koha fiturnya kurang lengkap dan belum mampu untuk memenuhi kebutuhan otomasi perpustakaan. Sistem otomasi ini juga merupakan sistem yang dirancang, dibuat dan dikembangkan sendiri oleh staf IT perpustakaan UMS. Ketika teknologi informasi semakin berkembang maka sistem otomasi ini seharusnya ikut dikembangkan menyesuaikan dengan kebutuhan dan perkembangan tersebut, namun pada kenyataannya staf IT yang merancang sistem ini merasa kewalahan dan angkat tangan untuk mengembangkan sistem otamasi yang telah dibuatnya.

Lebih jelasnya tahapan penerapan Koha di Perpustakaan UMS, dapat dilihat pada gambar 4 berikut ini :

\section{Gambar 4. Grafik Tahapan Penerapan Koha di Perpustakaan UMS}

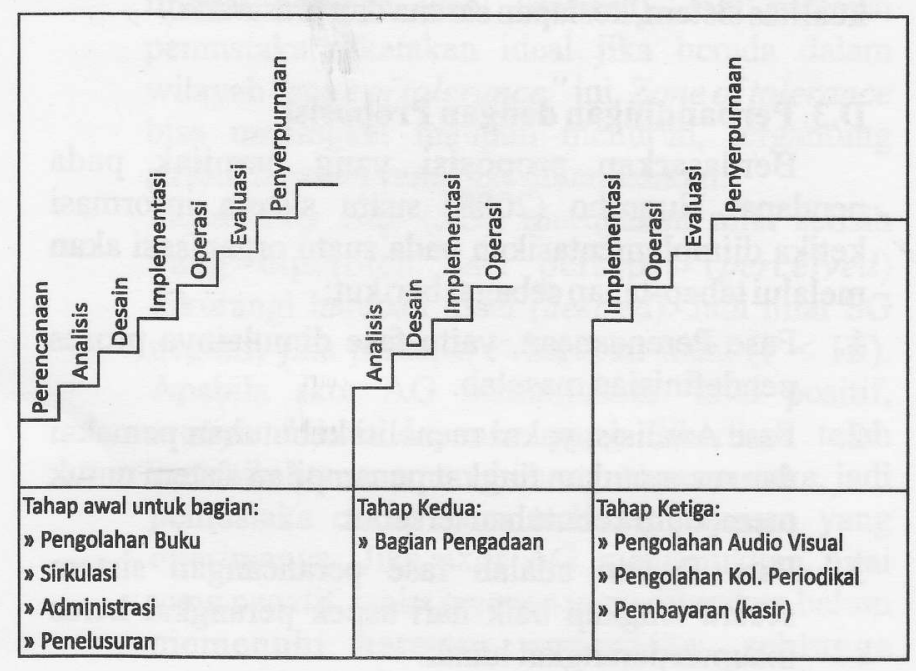

Cara penerapan Koha di Perpustakaan UMS dilakukan secara bertahap.

Pada awal implementasi hal-hal yang mampu difahami dari sistem otomasi Koha ini adalah sistem untuk bagian pengolahan, sirkulasi, pembayaran dan administrasi anggota. Untuk menerapkan sistem otomasi juga dibutuhkan kesiapan sarana dan prasarana serta SDM yang akan menjalankannya. Bagian yang pertama kali menjalankan sistem Koha ini adalah bagian pengolahan buku melalui kegiatan edit data secara berjamaah. Bagian ini dipilih karena bagian ini merupakan bagian yang paling sering mengalami masalah dengan sistem otomasi lama. Sehingga melalui kebijakan Kepala, SDM yang ada di bagian ini dituntut untuk siap melakukan proses peralihan pertama kali, begitu pula sarana dan prasarananya lebih disiapkan dan diutamakan dibanding bagian lain. Oleh karena itu pada tahap persiapan implementasi, orang-orang yang duduk di bagian pengolahan secara rutin dan intensif dilatih sistem Koha.

\section{D.2. Faktor-faktor yang mempengaruhi Penerapan Koha}

Berdasarkan penelitian dan hasil analisis yang dilakukan maka dapat diketahui bahwa faktor-faktor yang mendorong diterapkannya Koha di perpustakaan UMS adalah dukungan dari rektorat sebagai manajer tingkat tinggi di Universitas, SDM yang mempunyai kekuasaan dan kemampuan di bidang komputer, kesiapan SDM (tenaga terampil), trend perpustakaan yang menggunakan sistem otomasi berbasis web dan standar perpustakaan, integrasi, kebutuhan sistem, 
pengolahan data, komunikasi dan kerjasama yang baik, sosialisasi, open source, kondisi keuangan, kualitas sistem, kesiapan sarana dan prasarana.

\section{D.3. Perbandingan dengan Proposisi}

Berdasarkan proposisi yang berpijak pada pendapat Nugroho (2008) suatu sistem informasi ketika diimplementasikan pada suatu organisasi akan melalui tahap-tahap sebagai berikut:

1. Fase Perencanaan, yaitu fase dimulainya proses pendefinisian masalah.

2. Fase Analisis, yakni meneliti kebutuhan pemakai dan menentukan tingkat penampilan sistem untuk memenuhi kebutuhan tersebut.

3. Fase Desain adalah fase perancangan sistem secara lengkap baik dari aspek perangkat keras maupun perangkat lunak.

4. Fase Implementasi adalah fase di mana program ditulis, diuji dan disesuaikan sampai memenuhi kebutuhan pemakai.

5. Fase Operasi (Penggunaan) yakni fase di mana sistem mulai digunakan untuk membantu organisasi.

6. Fase Evaluasi (Penyempurnaan), yaitu peningkatan sistem.

Kenyataan yang terjadi di perpustakaan UMS dalam proses penerapan sistem informasi perpustakaan open source Koha ditemukan beberapa tahapan yang hampir sama dengan proposisi. Tahapantahapan tersebut adalah:

Tahap Perencanaan, tahun 2006, ketika Gunawan Ariyanto seorang ahli komputer masuk memimpin perpustakaan UMS. Proses perencanaan mulai kembali dijalankan, disini mulai dikumpulkan permasalahan-permasalahan yang sering terjadi dalam otomasi yang dipakai perpustakaan UMS. Akhirnya terbukalah beberapa permasalahan yang terjadi, di antaranya adalah masalah harian menyangkut data koleksi yang ada di komputer dengan data manualnya. Sistem otomasi yang digunakan sebelum Koha dinilai fiturnya kurang lengkap dan belum mampu untuk memenuhi kebutuhan dan tidak mengadopsi standar umum sistem otomasi perpustakaan. Selalu gagal bekerjasama dengan pihak luar. Banyaknya keluhan dari staf perpustakaan sendiri dan adanya desakan dari pihak Universitas untuk mengembangkan perpustakaan ke arah teknologi informasi

Dari beberapa permasalahan tersebut kemudian dilakukanlah tahap analisis kebutuhan. Tahap ini ditempuh dengan cara meminta data, informasi dan masukan melalui kaur dan staf perpustakaan tentang masalah-masalah yang berkenaan dengan sistem otomasi perpustakaan.

Mengirimkan beberapa orang staf untuk melakukan studi banding dan mengikuti lokakarya tentang pengembangan sistem informasi perpustakaan. Melakukan studi literatur dan komparasi terhadap beberapa software otomasi yang tersedia. Kemudian melakukan pemilihan, penilaian dan ujicoba di komputer lokal. Akhirnya terpilihlah Koha yang dinilai paling memenuhi kebutuhan Perpustakaan UMS.

Tahap selanjutnya dimulailah tahap desain sistem, pada tahap ini Perpustakaan UMS mengunduh Koha secara keseluruhan .Kepala Perpustakaan dan staf IT melakukan proses belajar dan pendalaman yang lebih inten terhadap Koha. Setelah proses pembelajaran kemudian dirancanglah sistem yang akan digunakan untuk kebutuhan otomasi perpustakaan. Dalam Koha sendiri oleh pengembangnya telah dirancang dan didesain yang disesuaikan dengan kebutuhan perpustakaan. Oleh karena itu Perpustakaan UMS hanya tinggal memilih fitur-fitur yang akan dipakai. Perpustakaan UMS juga mempersiapkan komputerkomputer dengan sistem operasi Linux. Selain open source Linux juga lebih compatible dengan Koha. Walaupun pada saat itu masih banyak komputer yang dimiliki perpustakaan yang berbasis windows. Namun hal ini tidak menjadi kendala yang berarti, karena Koha juga bisa diterapkan pada komputer dengan basis windows.

Tahap selanjutnya adalah tahap implementasi, pada tahap ini sistem yang sudah didesain oleh pengembang Koha dan dimodifikasi oleh Kepala Perpustakaan dan staf IT dipilih dan didiskusikan fiturfitur apa saja yang bisa dipakai dan fitur-fitur apa saja yang untuk sementara tidak dipakai. Pemilihan ini tentu berdasar kepada kebutuhan dan kemampuan SDM serta sarana yang dimiliki Perpustakaan UMS pada saat itu. Fitur-fitur yang dipilih pertama merupakan fitur-fitur dasar sistem otomasi perpustakaan. Di antaranya pengolahan buku, layanan sirkulasi dan layanan administrasi keanggotaan.

Tahap berikutnya adalah tahap operasi, tahap ini dilaksanakan bersamaan dengan dijalankannya program stock opname pada bulan Januari 2008. Pada tahap ini Koha langsung diterapkan sebagai pengganti sistem otomasi perpustakaan. Jadi sistem lama langsung diganti dengan sistem baru tanpa ada proses 
ujicoba di salah satu bagian. Hal ini dilakukan karena diyakini Koha mampu dan bisa langsung menggantikan sistem lama. Selain itu resiko yang dihadapi juga sudah diantisipasi terlebih dahulu, sehingga masalah-masalah yang timbul pada saat operasi masih bisa diatasi.

Evaluasi komprehensif secara tertulis sejak Koha diterapkan memang belum terlaksana. Namun evaluasi rutin untuk proses pengembangan dan perbaikan penerapan Koha di Perpustakaan UMS tetap dilaksanakan. Evaluasi ini dilakukan melalui rapatrapat rutin yang dilakukan Kepala bersama Kaur. Selain itu evaluasi juga dijalankan melalui masukanmasukan dari para staf sebagai pengguna Koha ataupun melalui keluhan-keluhan yang terjadi pada saat penerapan. Melalui rapat, masukan dan keluhan ini kemudian diteliti dan diambil tindakan untuk proses perbaikan dan pengembangan penerapan Koha di Perpustakaan UMS.

Setiap ada evaluasi rutin walaupun tidak tertulis, sistem Koha kemudian dibenahi dan diperbaiki untuk pengembangan lebih baik. Tahap pengembangan ini juga tergantụng pada kesiapan sarana prasarana, SDM dan juga kebijakan dari pimpinan.

Sementara jika dibandingkan dengan proposisi faktor-faktor yang mendorong diterapkannya Koha di Perpustakaan UMS ada yang sesuai, tetapi ada juga faktor yang tidak berpengaruh. Berdasarkan proposisi faktor-faktor yang mempengaruhi pengembangan sistem informasi menurut Burch dan Grunidski (1994) dalam Nugroho (2008) adalah : Integrasi, format tatap muka (user interface), kekuatan kompetitor, kualitas informasi, kebutuhan sistem, pengolahan data, faktor organisasi, kebutuhan untung rugi, faktor manusia, masalah hukum.

Sedangkan yang terjadi di Perpustakaan UMS adalah karena beberapa hal berikut ini:

Adanya trend bahwa perpustakaan-perpustakaan sudah menggunakan sistem otomasi perpustakaan yang berbasis web dan berstandar perpustakaan.

Kualitas sistem Koha sendiri yang berdasarkan literatur dan penelitian mempunyai keunggulankeunggulan dibanding sistem otomasi lainnya. Koha lebih mudah dipelajari dan difahami dan dari segi umur sistem pun Koha dinilai lebih lama karena Koha terus dikembangkan oleh pengembang dari berbagai negara. Sehingga Koha dianggap sesuai dengan kebutuhan sistem Perpustakaan UMS karena mudah dipelajari dan tidak khawatir ketinggalan zaman.

Jumlah koleksi yang dimiliki Perpustakaan UMS yang sudah banyak juga mampu ditangani oleh Koha. Karena dalam hal pengolahan data, Koha mampu mengolah dan menyimpan data dengan kapasitas yang besar.

Dukungan dan kepercayaan yang penuh dari pihak rektorat dan staf perpustakaan untuk mengembangkan penggunaan teknologi informasi di Perpustakaan UMS memperlancar proses penerapan Koha di Perpustakaan UMS.

Komunikasi dan kerjasama yang baik antar pimpinan, staf dan IT juga mempengaruhi proses penerapan Koha di Perpustakaan.

Kondisi keuangan yang ada juga berpengaruh, sehingga memaksa Perpustakaan UMS untuk memilih sistem open source yang bisa dijalankan dengan biaya yang murah. Selain itu open source juga bebas untuk di-download, dimodifikasi dan didesain sesuai kebutuhan. Karena open source kode-kode sistemnya bebas untuk dibuka, dipelajari dan dikembangkan. Kesiapan sarana dan prasarana juga mempengaruhi proses perjalanan penerapan Koha di Perpustakaan UMS.

Faktor yang paling berpengaruh dalam penerapan Koha di Perpustakaan UMS adalah SDM yang mempunyai kekuasaan dan kemampuan mempercepat proses implementasi dan pengembangan Koha.

SDM yang dimaksud di sini adalah pemegang jabatan tertinggi di perpustakaan yakni kepala perpustakaan. Seorang kepala yang mempunyai kemampuan komputer dan bahasa Inggris yang baik dapat mempercepat proses penerapan Koha di Perpustakaan UMS.

Karena dengan kekuasaan dan kemampuannya tersebut beliau bisa langsung mengambil kebijakan dan mengerjakannya sendiri. Berbeda dengan seorang kepala yang tidak mempunyai kemampuan komputer yang baik, ketika mengambil suatu kebijakan tentang Koha beliau harus mendelegasikannya kepada staf bagian IT.

Jika dipetakan dalam tabel, maka perbandingan proposisi dengan kenyataan di lapangan bisa dilihat pada tabel 1. 
Tabel 1. Perbandingan Faktor-faktor yang mempengaruhi dalam Penerapan Sistem Informasi yang dinyatakan dalam Proposisi vs Kenyataan di Perpustakaan UMS

\begin{tabular}{|l|l|}
\hline Faktor-faktor dalam Proposisi & Faktor-faktor yang terjadi di Perpustakaan UMS \\
\hline Integrasi & Integrasi \\
\hline Format tatap muka (User Interface) & - \\
\hline Kekuatan Kompetitor & $\begin{array}{l}\text { Trend Perpustakaan menggunakan sistem otomasi } \\
\text { berbasis web }\end{array}$ \\
\hline Kebutuhan Sistem & Kebutuhan Sistem \\
\hline Pengolahan Data & Pengolahan Data \\
\hline Faktor Organisasi & Dukungan Rektorat \\
\hline Kebutuhan Untung Rugi & Kondisi Keuangan \\
\hline Faktor Manusia & $\begin{array}{l}\text { SDM yang mempunyai kekuasaan, kemampuan dan } \\
\text { kemauan Kesiapan SDM (Tenaga Terampil) } \\
\text { Kepemimpinan }\end{array}$ \\
\hline Masalah Hukum & Open source, bebas membuka kode-kode sistem. \\
\hline Kualitas Informasi & Kualitas Sistem \\
\hline- & Sarana \& Prasarana \\
\hline- & Sosialisasi \\
\hline- & Komunikasi dan Kerjasama yang Baik \\
\hline
\end{tabular}

\section{DAFTAR PUSTAKA}

2006. Laporan Tahun Rektor UMS: disampaikan pada upacara harijadi ke-48 UMS Senin, 6 Dzulqa'idah 1427 H/27 November 2006. Surakarta: UMS

2007. Laporan Tahun Rektor UMS: disampaikan pada upacara harijadi ke-49 UMS Sabtu, 24 November 2007. Surakarta: UMS 2008. Laporan Tahunan Rektor UMS 2008. Surakarta: UMS

2004. Perpustakaan Perguruan Tinggi: Buku Pedoman. Jakarta: Depdiknas RI Dirjen Dikti.

2007. Perpustakaan Universitas Muhammadiyah Surakarta 2006-2007. Surakarta: Perpustakaan UMS.

.tth. Buku Panduan Perpustakaan Universitas Muhammadiyah Surakarta. Surakarta: Perpustakaan UMS.

Arianto, M. Solihin. 2010. Penguatan Pengembangan Kerjasama dengan Sistem Perpustakaan Terintegrasi Koha berbasis Open source. Makalah Seminar Sehari \& Pameran Buku "Mengupas Koha Open Source ILS: Software Otomasi Perpustakaan Multi Fitur \& Bertaraf Internasional" di Perpustakaan UMS Kamis, 14
Oktober 2010

Ardoni. 2005. Teknologi Informasi: Kesiapan Pustakawan Memanfaatkannya. Pustaha, Jurnal Studi Perpustakaan dan Informasi Vol.1 No.2 Desember 2005

Arif, Ikhwan. 2003. Konsep dan Perencanaan dalam Automasi Perpustakaan. Makalah Seminar dan Workshop Sehari "Membangun Jaringan Perpustakaan Digital dan Otomasi Perpustakaan menuju Masyarakat Berbasis Pengetahuan“ UMM 4 Oktober 2003

Breeding, Marshall. 2009. Opening Up Library Automation Software. Dalam Computers In Libraries: The Systems Librarian. Ferbruary, 2009

Breeding, Marshall. 2008. Open source Integrated Library Systems Chapter 3: Major Open Source ILS Product. Jurnal Library Technology Reports edisi Nov/Des 2008

Herdiansyah, Haris. 2010. Metodologi Penelitian Kualitatif untuk ilmu-ilmu Sosial. Jakarta: Salemba Humanika

http://library.ums.ac.id Akses 15 April 2011

Ishak. 2008. Pengelolaan Perpustakaan Berbasis Teknologi Informasi. Dalam Pustaha, Jurnal Studi Perpustakaan dan Informasi Vol.4 No.2 Desember 2008 
Jogiyanto. 2009. Sistem Teknologi Informasi.-Ed.3. Yogyakarta: Andi

Jogiyanto. 2008. Sistem Informasi Keperilakuan. Yogyakarta:Andi

Kochar, R.S. \& Sudarshan, K.N. Library Automation (Issues and systems)

Kismiyati, Titiek. 2004. Kompetensi teknologi informasi dalam paradigma baru perpustakaan (Tesis). Jakarta: Progdi Ilmu Perpustakaan, Fakultas Ilmu Budaya, UI.

Mahmudin. 2008. Pemanfaatan ICT (Information and Communication Technology) Di Perpustakaan dalam http://duniaperpustakaan.com/2010/ $04 / 20 /$ pemanfaatan-ict-information-andcommunication-technology-di-perpustakaan/ Akses 19Agustus 2010 14:10

Makarim, Edmon \& Brian Amy Prastyo. 2007. “ Peraturan dan Etika dalam Dunia Digital" dalam buku Perpustakaan Digital: Perspektif perpustakaan Perguruan Tinggi Indonesia, Jakarta: Sagung Seto \& Perpustakaan UI.

McCallum. 2003. 40 Years of Technology in Libraries: A Brief History of the IFLA Section on Information Technology, 1963/64 - 2003. Hasil Konferensi IFLAdi Berlin.

Nugroho, Eko. 2008. Sistem Informasi Manajemen: Konsep, Aplikasi, \& Perkembangannya. Yogyakarta:Andi

Pendit, Putu Laxman. 2007. " Pengantar" dalam buku Perpustakaan Digital: Perspektif Perpustakaan Perguruan Tinggi Indonesia, Jakarta: Sagung Seto \& Perpustakaan UI.

Priyanto, Ida Fajar. 2010. Teknologi Informasi, perpustakaan dan pengembangannya. Makalah Seminar Sehari \& Pameran Buku "Mengupas Koha Open Source ILS: Software Otomasi Perpustakaan Multi Fitur \& Bertaraf Internasional" di Perpustakaan UMS Kamis, 14 Oktober 2010

Ruldeviani, Yova \& Yudho Giri Sucahyo. 2007. “
Infrastruktur Perpustakaan Digital" dalam dalam buku Perpustakaan Digital: Perspektif perpustakaan Perguruan Tinggi Indonesia, Jakarta: Sagung Seto \& Perpustakaan UI.

Sangkala. 2007. Knowledge Management: Suatu Pengantar memahami bagaimana organisasi mengelola pengetahuan sehingga menjadi organisasi yang unggul. Jakarta: Raja Grafindo Persada

Saleh, Abdul Rahman. Tahukah anda Sejarah Perpustakaan Indonesia. Jurnal Pustakawan Indonesia, Volume 6 Nomor 1

Suhardini, Dini. Penerapan Teknologi Informasi di Perpustakaan: Perspektif mekanisme perpustakaan digital. Makalah. Perpustakaan Univ. Pendidikan Indonesia

Sutarno NS. 2006. Perpustakaan dan Masyarakat. Jakarta: Sagung Seto

Sutarno NS. 2008. 1 Abad kebangkitan Nasional \& Kebangkitan Perpustakaan. Jakarta: Sagung Seto

Sulistyo-Basuki. 1994. Periodisasi Perpustakaan Indonesia. Bandung: Remaja Rosdakarya

Suwanto, Sri Ati. 2003. Teknologi Informasi untuk Perpustakaan dan Pusat Dokumentasi dan Informasi. Makalah disampaikan pada Diklat Teknis Perpustakaan dan Dokumentasi Propinsi Jateng.

Wijayanti, Luki \& Putu Laxman Pendit. 2007. "Merintis dan Membangun Kerjasama" dalam buku Perpustakaan Digital: Perspektif perpustakaan Perguruan Tinggi Indonesia, Jakarta: Sagung Seto \& Perpustakaan UI.

Widodo. 2009. Implementasi Teknologi Informasi di Perpustakaan. Artikel. Dalam http://widodo.staff.uns.ac.id/2009/05/26/implem entasi-teknologi-informasi-di-perpustakaan/ Akses 20 Agustus 2010 15:04

Yin, Robert K. 2009. Studi Kasus: Desain \& Metode. Jakarta: Raja Grafindo Persada. 